\title{
Statyba
}

\section{INVESTIGATION OF DAMPNESS DAMAGE IN THE HOUSE OF THE LITHUANIAN INDEPENDENCE SIGNATORIES}

\section{Č. Ignatavičius}

To cite this article: Č. Ignatavičius (2001) INVESTIGATION OF DAMPNESS DAMAGE IN THE HOUSE OF THE LITHUANIAN INDEPENDENCE SIGNATORIES, Statyba, 7:3, 247-253, DOI: 10.1080/13921525.2001.10531731

To link to this article: https://doi.org/10.1080/13921525.2001.10531731

曲 Published online: 30 Jul 2012.

Submit your article to this journal $₫$

Џ Article views: 46 


\section{LIETUVOS NEPRIKLAUSOMYBĖS SIGNATARU NAMU GEDIMU,, SUSIJUSIŲ SU DRĖGME, NATŪRINIAI TYRIMAI}

\section{Č. Ignatavičius}

Vilniaus Gedimino technikos universitetas

\section{Ivadas}

Per pastaraji dešimtmetị Lietuvoje labai padaugejo rekonstruojamy pastaty [1]. Geri specialistai, naudodami naujas medžiagas ir taikydami naujausias technologijas, senus, apgriuvusius namus paverčia moderniais pastatais. Tačiau suremontuoti seną pastatą taip, kad jis atitiktu ne tik estetinius, bet ir šiuolaikinius komforto reikalavimus [2], ne taip paprasta. Tai akivaizdžiai ịrodo Lietuvos Nepriklausomybès signatarų namų gedimai, atsiradę po pastato rekonstrukcijos. Nors praejo tik dveji metai po rekonstrukcijos, o jau pastato rūsyje tvyro drègmè, vystosi mikromicetai, jaučiamas nemalonus kvapas, atitvarų paviršiuje matyti druskos, sienц bei lubu tinkas jau yra pūslètas, nuo jo lupasi dažai, vietomis matyti vandens tekèjimo žymès. Neremontuojamas pastatas dar labiau ges, trumpès jo eksploatacijos trukmè, didès gedimu taisymo kaina, pastatas vèl taps nereprezentacinis ir nevertingas [3]. Siekiant panaikinti išvardytus gedimus, buvo nuspręsta atlikti jụ natūrinius tyrimus.

Vizualinè pastato apžiūra parodè, kad pastato gedimai yra susiję su drègmès poveikiu. Tačiau buvo neaišku, kaip drègmè patenka i pastata, kaip ji veikia jo apdaila, mikroklimata, kokie yra mikroklimato parametrai, ar pastato rūsys tinka viešosios paskirties patalpoms, kaip tai numatyta pastato rekonstrukcijos projekte. Buvo suformuluotas toks natüriniu tyrimų tikslas: laboratoriniais prietaisais ištirti rūsio išoriniu sienu vandens pralaidumą ir jo ịtaką rūsio atitvarų apdailai, ìvertinti rūsio patalpu mikroklimato parametrus.

\section{Tyrimų metodika}

Šiuose tyrimuose buvo pasinaudota Vokietijos pastaty eksploatavimo ir modernizavimo instituto patyrimu [4]. Rūsio išorinių sienų vandens pralaidumui tirti pasirinktos trys vietos Pilies bei Literatu gatvèse ir kieme (1 pav.). Tose vietose buvo išardyti šaligatviai atidengta žemé ir ant jos lietintas miesto vandentiekio vanduo. Lietinta visur po $3,5 \mathrm{~h}$, jo intensyvumas visose vietose buvo vienodas $-250 \mathrm{l} / \mathrm{h}$.

Patalpų viduje, ten, kur iš lauko pusès buvo lietinta, trijuose lygiuose $-10 \mathrm{~cm}, 110 \mathrm{~cm}$ ir $210 \mathrm{~cm}$ nuo grindu paviršiaus buvo imami tinko mèginiai ir kalcio-karbido metodu [3] nustatomas ju drègnis. Jis buvo nustatomas prieš rūsio sienų lietinimą, po $24-26 \mathrm{~h}$ ir po 48-50 h nuo lietinimo pradžios. Kartu buvo matuojamos atitvarų ir grindụ paviršiaus bei oro temperatūra ir santykinis oro drègnis patalpu viduryje, kaip to reikalaujama Lietuvos higienos normoje HN42-1999. Santykinis oro drègnis prie atitvarų paviršiaus buvo apskaičiuojamas pagal formulę:

$$
\phi_{s i}=\left(p_{v} / p_{s i}\right) \cdot 100, \% ;
$$

$p_{v}$ - dalinis vandens garu slègis patalpos viduryje, $\mathrm{Pa}$; $p_{s i}$ - sočiuju vandens garu slègis prie atitvaru paviršiaus, $\mathrm{Pa}$.

Pastato tyrimai buvo atliekami 1999 metais spalio lapkričio mènesiais.

\section{Tyrimų rezultatų analizė}

Matavimų ir skaičiavimų rezultatai pateikti lentelèje ir 2-6 pav. Rezultatai rodo, kad rūsio išorinių sienu tinko drègnis yra artimas normaliam eksploataciniam $2 \%$ drègniui [3] tik trijuose taškuose iš penkiolikos, t. y. R6-10, R6-110 ir R6-210. Kituose dvylikoje taškų tinko drégnis buvo gerokai didesnis. R2-10, R3-10, R3-110 ir R3-210 vietose tinkas buvo prisotintas drègmès, t. y. $\geq 10 \%$. Po $3 \mathrm{~h}$ išorinio žemès lietinimo Pilies gt. penkioliktoje rūsio patalpoje ant išorinès sienos, apatinèje R2 vietoje pasirodè akivaizdžios tekančio vandens čiurkšlès. Po $24 \mathrm{~h}$ nuo lietinimo pradžios ir po 


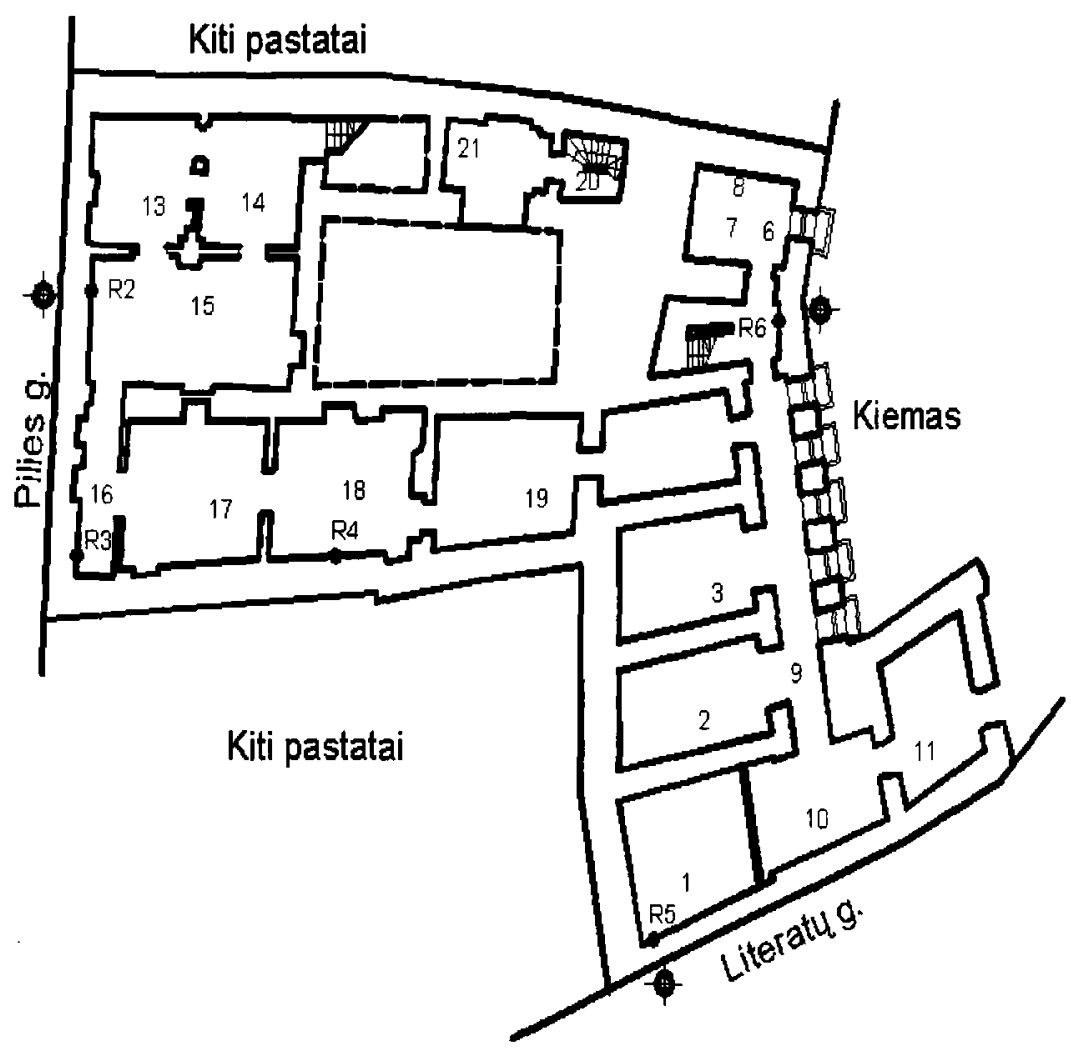

\footnotetext{
- R2 -R6 - meginiu, skirtu dregminiams tyrimams èmimo ir temperatūru matavimo vietos

žemés lietinimo vietos
}

1 pav. Lietuvos Nepriklausomybès signataru namų rūsio planas

Fig 1. Map of the House of the Lithuanian Independence Signatories cellar

$21,5 \mathrm{~h}$ baigus lietinti R2 vietoje apatiniame R2-10 taške tinkas liko prisotintas drègmès (2 pav.), aukščiau viduriniame taške R2-110 tinko drégnis padidèjo nuo $8 \%$ iki $9,7 \%$, dar aukščiau - viršutiniame taške R2-210 jis padidejo nuo $9,2 \%$ iki $9,8 \%$. Po 48 h nuo lietinimo pradžios tinko drègnis liko artimas drègniui, nustatytam po $24 \mathrm{~h}$. Tai galima paaiškinti tuo, kad rūsio sienos vanduo nebedrékino jau 44,5 h. Lietinant žemę Literatu gt., pirmoje rūsio patalpoje ant išorinès sienos, R-5 vietoje vandens čiurkšlių nepastebèta, tačiau tinko drègnis po lietinimo padidèjo (5 pav.): R5-10 vietoje - nuo $8,2 \%$ iki 8,6\%, R5-110 vietoje - nuo $6,2 \%$ iki $8,1 \%$, o R5-210 vietoje - nuo 9,2\% iki prisotinimo. Lietinant žemę kieme, penktoje rūsio patalpoje ant išorès sienos santykinai sausoje R6 vietoje drègnis irgi pakito, tačiau nežymiai (6 pav.): R6-10 - nuo 2\% iki 2,1\%, R6-110nuo $1,4 \%$ iki $2,2 \%$, R6-210 - nuo $1,6 \%$ iki $2,3 \%$. Nežymus tinko drégnio padidẻjimas rūsio penktoje patal- poje gali būti susijęs su geresniu rūsio išorinès sienos sandarumu, galèjo būti sausesnè kieme esanti žemè - ji daugiau sugèrè ar „nuleido“ žemyn lietinamą vandenị ir jo mažiau teko rūsio sienoms. Be to, ttakos galèjo turèti ir tai, kad ši patalpa yra laiptu narvelyje, ji gerai vèdinama ir gerai apšildoma, dèl to drégmè iš tinko geriau išgaruoja.

Rūsio išorinių sienu tinko drègnio didejjimas ir vandens čiurkšlių atsiradimas ant sienų patalpose, lietinant išorèje esančią žemę, irodo, kad jos praleidžia vandenį. Per rūsio išorines sienas prasiskverbusi drègmè ant jų paviršiaus išneša druskas, dèl to sienų paviršius patalpose tapo démetas, vietomis ant jų susidarè net druskų „šerkšnas“. Be to, drègmè garuoja ir didina oro drègni pastate ir jo konstrukcijose. Apskaičiavimai, atlikti pagal [5] formulę (2), parodè, kad vien tik nuo $1 \mathrm{~m}^{2}$ tokių drègnụ paviršių i patalpụ orą per $1 \mathrm{~h}$ gali išgaruoti nuo $15,6 \mathrm{~g}$ iki $31,2 \mathrm{~g}$ drègmès: 


$$
G_{d r}=(a+0,017 v)\left(p_{2}-p_{1}\right) \cdot \frac{760}{p_{b a r}} \cdot A, \mathrm{~kg} / \mathrm{h},
$$

$G_{d r}$ - išgaravusios dregmès kiekis, $\mathrm{kg} / \mathrm{h} ; a$ - koeficientas, priklausantis nuo temperatūros; $v$ - oro judèjimo greitis, $\mathrm{m} / \mathrm{s} ; p_{2}-p_{1}-$ dalinio vandens garu slègio virš vandens paviršiaus ir patalpos ore skirtumas, $\mathrm{mm}$ $\mathrm{Hg} ; p_{b a r}$ - barometrinis atmosferos slègis, $\mathrm{mm} \mathrm{Hg}$; $A$ - garavimo paviršius, $\mathrm{m}^{2}$.

Rūsio patalpụ oro santykinio drègnio matavimai parodè, kad jis nagrinètose rūsio patalpose buvo nuo $75,4 \%$ iki $88,3 \%$, t. y. daug didesnis už Lietuvos higienos normoje HN42:1999 nurodyta šiluminio komforto maksimalu drègni $-60 \%$. Mažiausias oro santykinis drègnis buvo penktoje patalpoje $-75,4 \%$, kur sienos buvo sausiausios. Ten, kur sienų drègnis buvo didesnis, oro santykinis drègnis irgi didesnis, išskyrus aštuonio- liktą patalpą. Šioje patalpoje rūsio išorinès sienos tinko vidutinis drègnis buvo santykinai mažas $-5,4 \%$, o oro santykinis drègnis didelis $-85,2 \%$. Tam galèjo turèti itakos kitu patalpu didelè oro drègmè, kuri per atviras duris galèjo patekti į šią patalpa arba prigaruoti iš kitụ nepastebètų drègnesnių sienos vietų.

Oro santykinis drègnis prie rūsio išoriniu sienu paviršiaus buvo nuo $95,3 \%$ iki $100 \%$ (rasos taškas). Tai irgi gerokai didesnis nei maksimalus leistinasis oro santykinis drègnis (80\%) [6]. Toks didelis oro drègnis prie atitvarų paviršiaus sudare palankias sąlygas mikromicetams daugintis [7]. Doc. dr. O. Motiejūnaitė, atlikusi mikologinius tyrimus, nustatè, kad Nepriklausomybès signatarụ namuose paplitusios net 26 mikromicetu rūšys. Susirūpinimą kelia tai, kad rūsio patalpose plinta Trichophyton genties mikromicetai, kurie yra pavojingi

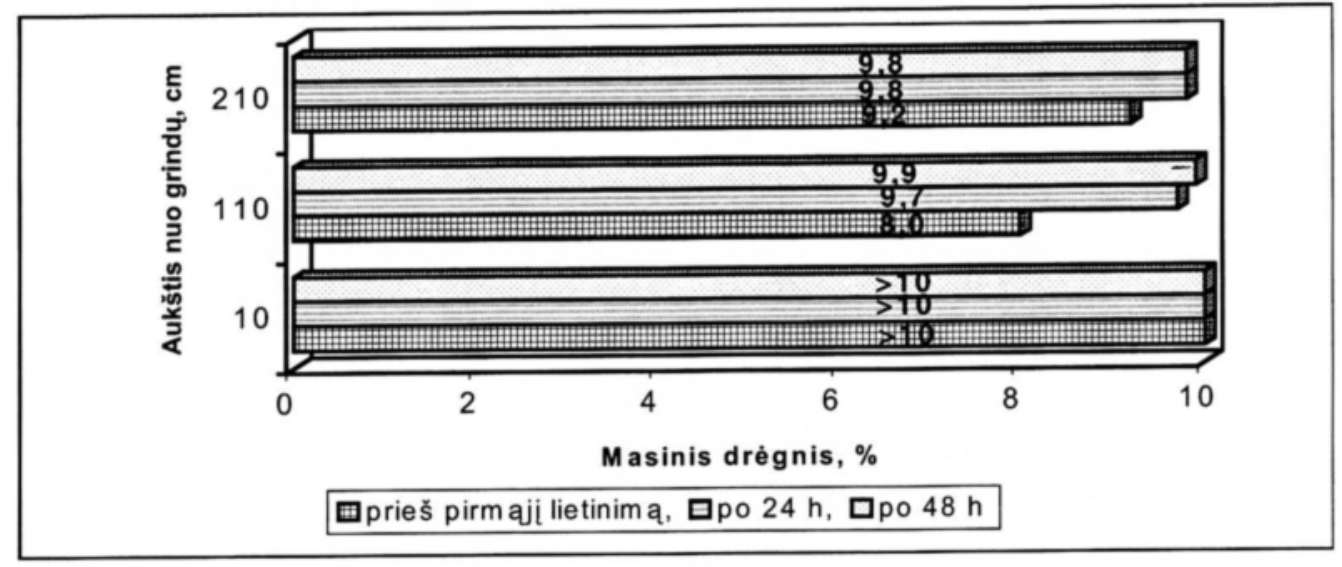

2 pav. Rūsio penkioliktos patalpos lietintos išorinès sienos masiniai drègniai R2 vietoje

Fig 2. Mass humidities on the outer poured wall R2 place of the 15th cellar room

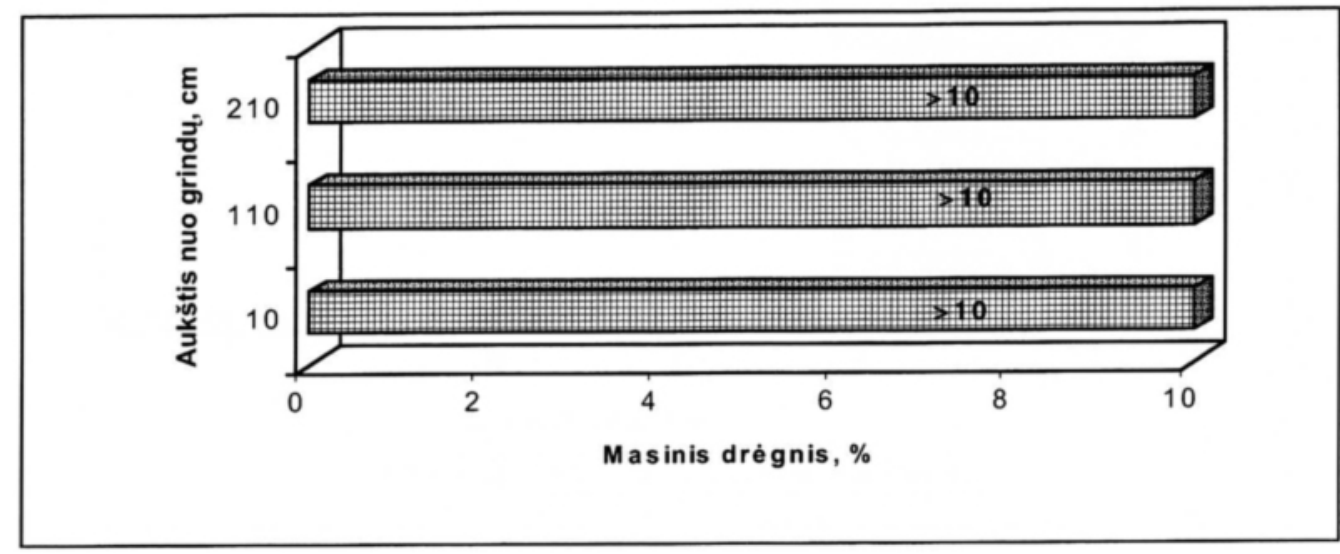

3 pav. Rūsio šešioliktos patalpos nelietintos išorinès sienos tinko masiniai drègniai R3 vietoje

Fig 3. Mass humidities of the plaster on the outer non-poured wall R3 place of the 16th cellar room 


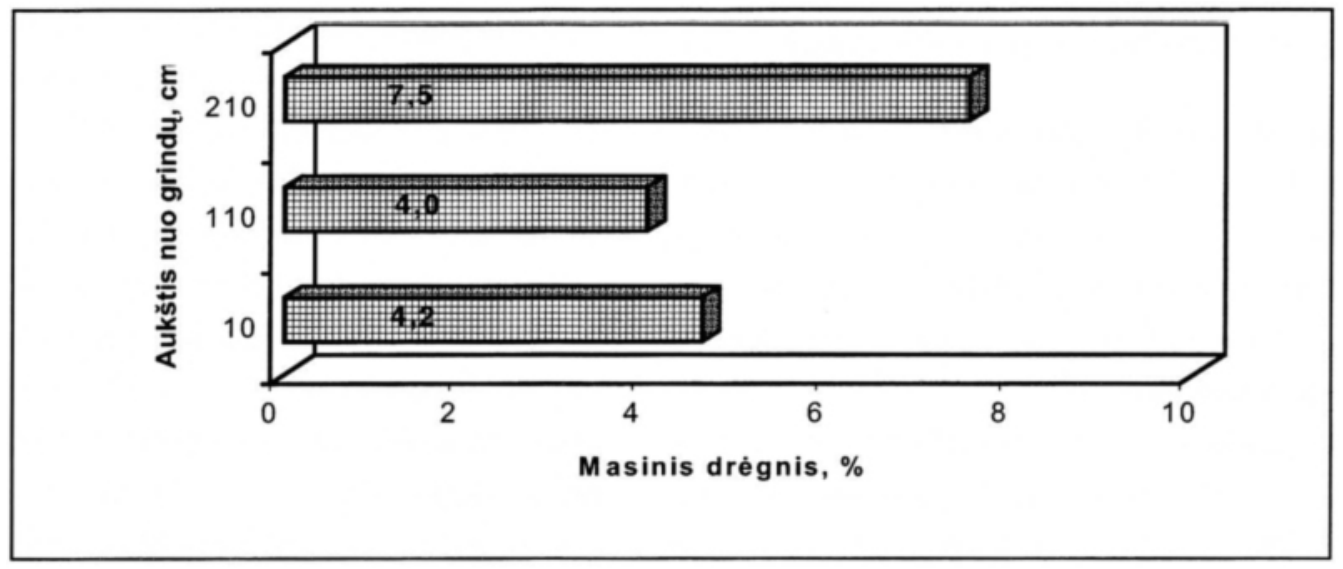

4 pav. Rūsio aštuonioliktos patalpos nelietintos išorinès sienos tinko masiniai drègniai R4 vietoje

Fig 4. Mass humidities of the plaster on the outer non-poured wall R4 place of the 18th cellar room

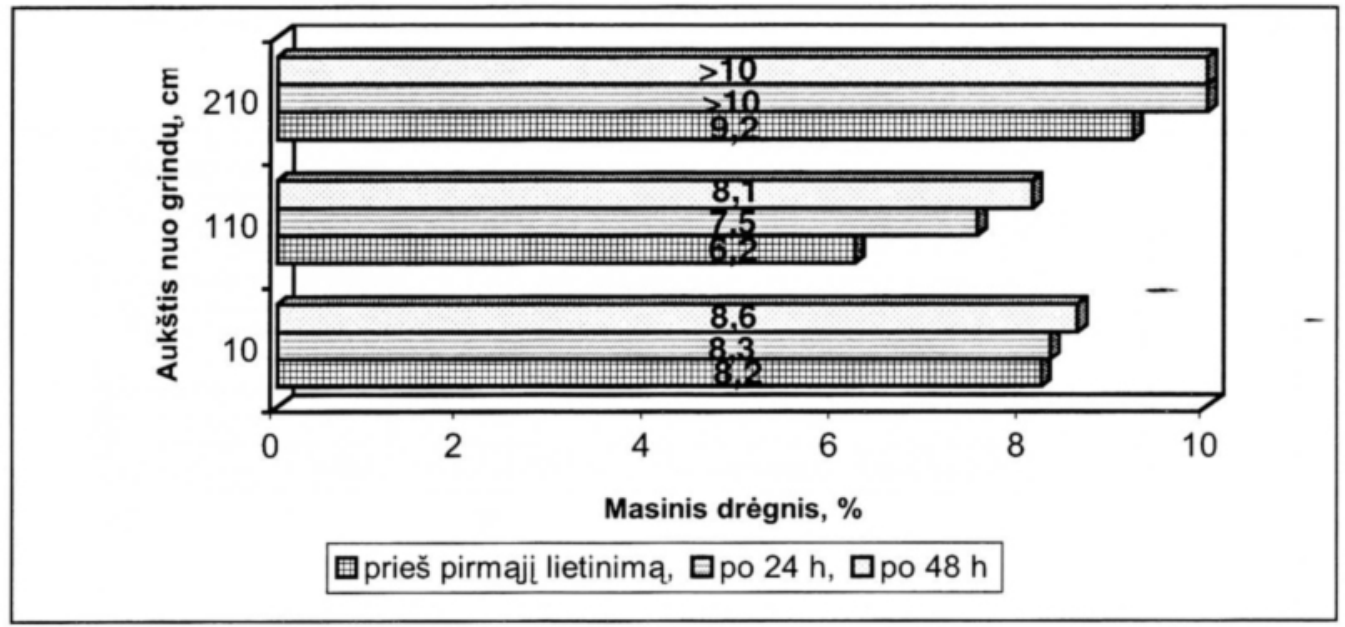

5 pav. Rūsio pirmos patalpos lietintos išorinès sienos tinko masiniai drègniai R5 vietoje

Fig 5. Mass humidities of the plaster on the outer non-poured wall R5 place of the lth cellar room

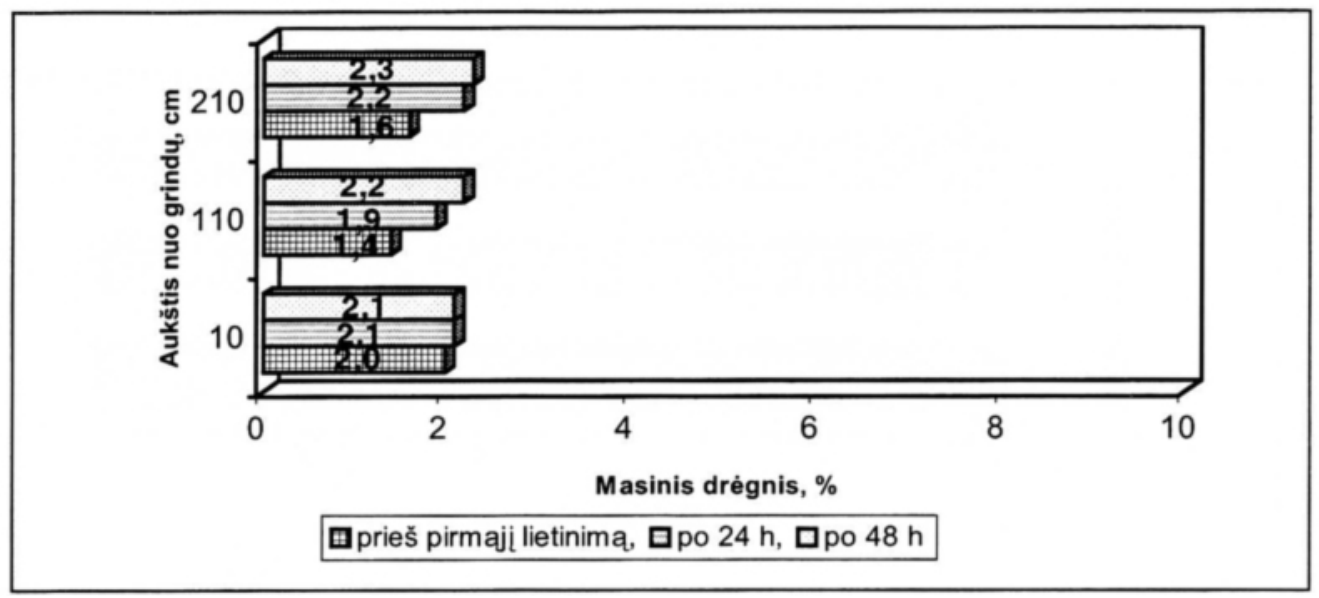

6 pav. Rūsio penktos patalpos lietintos išorinès sienos tinko masiniai drègniai R6 vietoje

Fig 6. Mass humidities of the plaster on the outer non-poured wall R6 place of the 5 th cellar room 


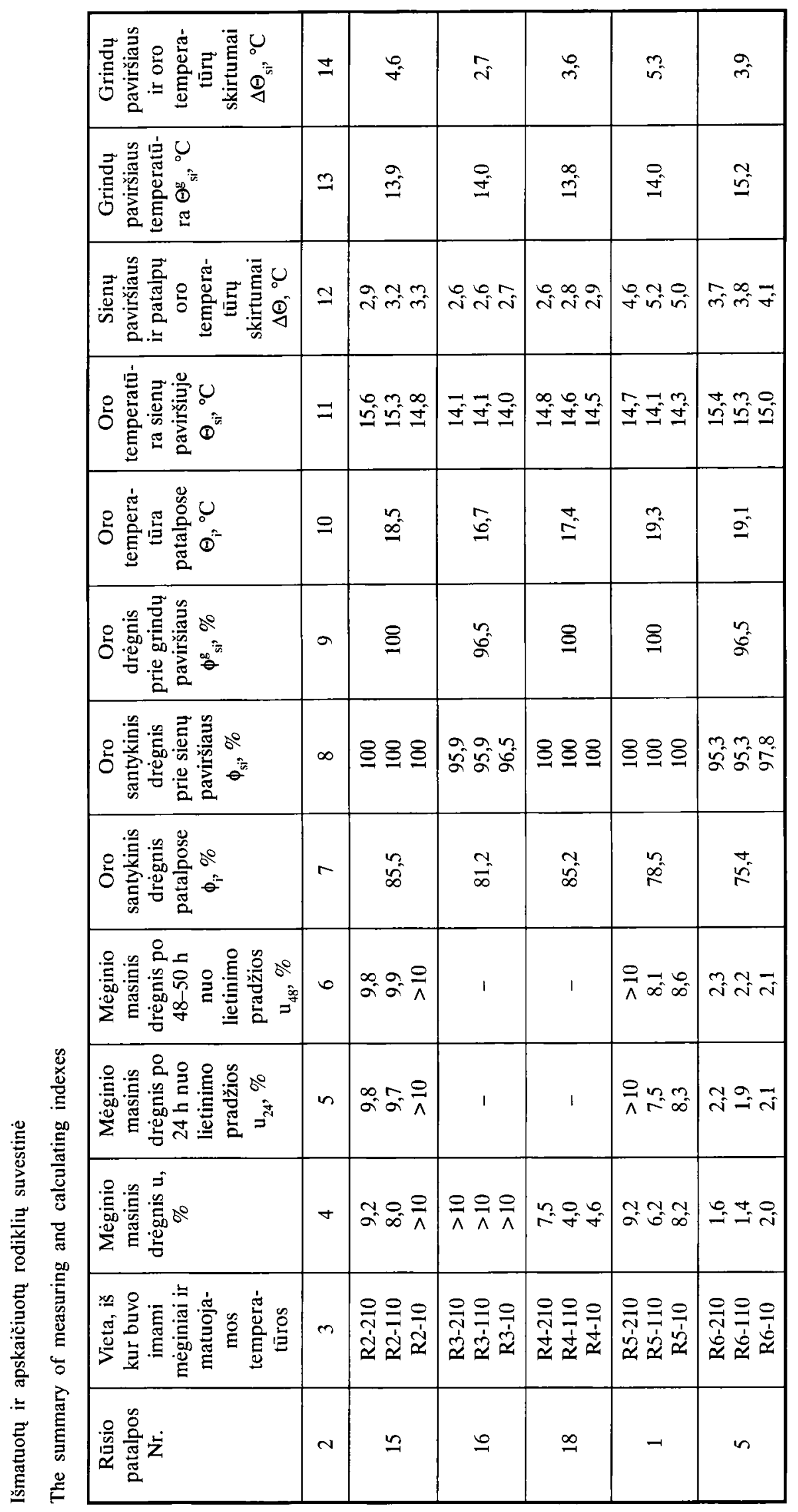


žmogaus sveikatai ir gali sukelti odos bei nagų ligas. Be to, mikromicetai, esantys ant atitvarų paviršiaus, ardo atitvaru apdaila - ji atrodo dèmèta. Tokia neestetiška antisanitarinè aplinka netinka žmoniụ veiklai.

Temperatūrų matavimai parodè, kad rūsio patalpu viduryje, $110 \mathrm{~cm}$ aukštyje nuo grindu paviršiaus, oro temperatūra $\Theta_{i}$ buvo nuo $16,7^{\circ} \mathrm{C}$ iki $19,3^{\circ} \mathrm{C}$. Sienu paviršiaus temperatūra $\Theta_{s i}$ buvo nuo $14,1^{\circ} \mathrm{C}$ iki $15,6^{\circ} \mathrm{C}$, o grindụ paviršiaus temperatūra $\Theta_{s i}^{g}$ buvo nuo $13,9^{\circ} \mathrm{C}$ iki $15,2^{\circ} \mathrm{C}$. Patalpų oro temperatūros $\Theta_{i}$ skirtumas nuo sienų paviršiaus temperatūros $\Theta_{s i}$ buvo nuo $2,6^{\circ} \mathrm{C}$ iki $5,2^{\circ} \mathrm{C}$, o skirtumas tarp $\Theta_{i}$ ir grindų paviršiaus temperatūros $\Theta_{s i}^{q}$ buvo nuo $2,7^{\circ} \mathrm{C}$ iki $5,3^{\circ} \mathrm{C}$. Pagal Lietuvos higienos normos HN42:1999 reikalavimus sienu paviršiaus temperatūra gali skirtis nuo patalpu oro temperatūros iki $2^{\circ} \mathrm{C}$, o grindụ paviršiaus temperatūra - iki $3^{\circ} \mathrm{C}$. Tai rodo, kad rūsio patalpụ temperatūru skirtumai neatitinka šių reikalavimų. Tokị dideli sienų ir grindų paviršiaus temperatūru skirtumą nuo patalpu oro temperatūros galima paaiškinti tuo, kad tokio drègnumo rūsio sienos ir grindys, kurios neturi papildomo apšiltinimo, pasižymi dideliu šilumos laidumu. Apskaičiavimai, atlikti pagal formulę (3) [6], rodo, kad šiuo metu rūsio išorinių sienų šilumos perdavimo koeficientas $U$ yra nuo $1,87 \mathrm{~W} / \mathrm{m}^{2} \mathrm{~K}$ iki $3,18 \mathrm{~W} / \mathrm{m}^{2} \mathrm{~K}$, o grindų konstrukcijų nuo $1,59 \mathrm{~W} / \mathrm{m}^{2} \mathrm{~K}$ iki $2,48 \mathrm{~W} / \mathrm{m}^{2} \mathrm{~K}$, tuo tarpu sauso rūsio išoriniu sienų teorinis šilumos perdavimo koeficientas $U \approx 0,8 \mathrm{~W} / \mathrm{m}^{2} \mathrm{~K}, \quad$ o grindu konstrukcijos $U^{g} \approx 2,0 \mathrm{~W} / \mathrm{m}^{2} \mathrm{~K}$ :

$$
U=\frac{h_{s i}\left(\Theta_{i}-\Theta_{s i}\right)}{\Theta_{i}-\Theta_{l}^{g r}}, W / m^{2} K,
$$

$h_{s i}$ - rūsio patalpų išorinių sienų ir grindu paviršiaus šilumos perdavimo koeficientas sienoms $7,7 \mathrm{~W} / \mathrm{m}^{2} \mathrm{~K}$, grindims $5,9 \mathrm{~W} / \mathrm{m}^{2} \mathrm{~K} ; \Theta_{i}$ - oro temperatūra patalpos viduryje, ${ }^{\circ} \mathrm{C} ; \Theta_{s i}$ - rūsio patalpų išorinių sienų ar grindụ paviršiaus temperatūra, ${ }^{\circ} \mathrm{C} ; \Theta_{e}^{g r}$ - grunto temperatūra prie pamato ar grindu.

Teoriniai temperatūrų skirtumų skaičiavimai pagal STR 2.05.01:1999 rodo, kad, kai tokios šilumos perdavimo koeficientų reikšmès, žiemą gali atsirasti neleistinч temperatūros skirtumu. Tad norint, kad patalpos atitiktụ higienos normų reikalavimus, būtina ne tik sutvarkyti hidroizoliacija bet ir papildomai apšiltinti rüsio sienas bei grindis.

\section{Išvados}

1. Lietuvos Nepriklausomybès signatarų namų išorinių rūsio sienų apsauga nuo drègmès yra nepakankama, sienos i pastato vidų praleidžia drègmę po $3 \mathrm{~h}$ nuo išorèje esančios žemès lietinimo pradžios. Dèl to pro sienas skverbiasi ir ant ju paviršiaus nusẻda ivvairios druskos, blogèja patalpu mikroklimatas.

2. Rūsio patalpụ viduje santykinis drègnis yra didesnis už normuojamą (HN42:1999) maksimalu 60\% drègni. Tyrimu laikotarpiu rūsio patalpose jis buvo nuo $75,4 \%$ iki $85,2 \%$.

3. Santykinis oro drègnis prie išorinių rūsio sienų bei grindu paviršiaus yra didesnis už normuojamą (STR $2.05 .01: 1999$ ) $80 \%$ drègni, tyrimų laikotarpiu jis buvo nuo $95,3 \%$ iki $100 \%$. Tai sudare palankias sąlygas mikromicetams vystytis.

4. Rūsio patalpų oro temperatūros skirtumas nuo sienu bei grindu yra didesnis už normuojamą (HN42:1999) temperatūrų skirtumą - nuo sienų paviršiaus temperatūros iki $2^{\circ} \mathrm{C}$, nuo grindu paviršiaus iki $3^{\circ} \mathrm{C}$, tyrimu metū patalpy oro temperatūra skyrèsi nuo sienų paviršiaus iki $5,2^{\circ} \mathrm{C}$, o nuo grindų - iki $5,3^{\circ} \mathrm{C}$.

5. Lietuvos Nepriklausomybès signatarų namų rūsys, toks, koks yra šiuo metu, netenkina Lietuvos higienos normos HN42:1999 reikalavimu ir dèl to netinka viešosios paskirties patalpoms. Būtina sutvarkyti pastato hidroizoliaciją ir papildomai apšiltinti rūsio išorines sienas bei grindis.

\section{Literatūra}

1. V. Kaminskas. Statybinès medžiagos (Energijos sąnaudų mažinimo statybinių medžiagu pramonèje strategija). Vilnius: Valgra, 2000. $171 \mathrm{p}$.

2. Lietuvos higienos norma HN42-1999. Gyvenamuju ir viešosios paskirties pastaty mikroklimatas. Vilnius: Lietuvos higienos institutas, 1999. $13 \mathrm{p}$.

3. Dzierzon /Zull. Altbauter Zerstörungsarm Untersuchen. Köln: Verlagsgesellschaft Rudolf Müller GmbH, 1990 $177 \mathrm{~S}$.

4. Institut für Erhaltung und Modernisierung von Bauwerken e.v. Prüfverfahren. Berlin: IRB Verlag, 1995. $98 \mathrm{~S}$.

5. E. Juodis. Vèdinimas. Vilnius: Enciklopedija, 1998. 352 p.

6. Techninių reikalavimy reglamentas, STR 2.05.01:1999 Pastatu atitvaru šiluminé technika. Vilnius: Lietuvos Respublikos aplinkos ministerija, 1999. $61 \mathrm{p}$.

7. H. Buss. Schimmelpilze in Wohnungen. WEKA Fachverlage GmbH. Baufachverlag, Kissing, 1991. 157 S.

Iteikta 20001002 


\section{INVESTIGATION OF DAMPNESS DAMAGE IN THE HOUSE OF THE LITHUANIAN INDEPENDENCE SIGNATORIES}

\section{Č. Ignatavičius}

\section{Summary}

After the reconstruction of the House of the Lithuanian Independence Signatories the microclimate of its basement is damp, mycelium microorganisms, salt efflorescence occur on the enclosure wall surfaces, efflorescence and bubbles form on the facing of the walls and ceiling and an unpleasant smell appears in the building. Full-scale tests performed show that the protection of the basement exterior walls from damp is insufficient. On one spot of the outside ground the drained storm water penetrated through the basement exterior walls and streamed into the building after three hours from the beginning of the storm-water drainage. No water streams inside the building were observed at an other two storm-water drainage spots but the plaster humidity in the basement exterior walls inside the building was increased after the stormwater drainage on the outside ground. This dampness favoured the efflorescence of various salts on the facing of the basement walls and other building structures.

Testing the basement air humidity showed that the relative air humidity in the middle of the basement space was $75.485 .2 \%$. It exceeds the maximum normative relative air humidity of $60 \%$. The relative air humidity near the surfaces of the walls and floor was $95.3-100 \%$. It exceeds the maximum normative relative air humidity of $80 \%$. Such a high relative air humidity favoured the development of various mycelium microorganisms.

Temperature analyses of the basement space showed that its air temperature differed from that of the wall and floor surfaces by up to $5.2^{\circ} \mathrm{C}$ and by up to $5.3^{\circ} \mathrm{C}$, respectively. These temperature differencies exceed the maximum normative temperature difference of up to $2^{\circ} \mathrm{C}$ and up to $3^{\circ} \mathrm{C}$ for wall and floor surfaces, respectively. Such significant temperature differencies cause a great thermal discomfort.

On the basis of the investigation results presented, it can be stated that the basement in the House of the Lithuanian Independence Signatories is unsuitable for a public building.

Česlovas IGNATAVIČIUS. Doctor, Associate Professor. Dept of Building Structures, Vilnius Gediminas Technical University (VGTU, formerly VTU), Sauletekio al. 11, LT-2040 Vilnius, Lithuania. E-mail: IC@takas.lt

$\mathrm{PhD}$ (civil engineering), Vilnius Civil Engineering Institute (1973, VISI, now VGTU). First degree in Civil Engineering, Kaunas Polytechnic Institute (1964). Research visits: Munich Technical University (Germany, 1980-81). Horsens Polytechnic Institute (Denmark, 1994). Moscow Institute of Architecture (Russia, 1985). Author of over 40 scientific articles. Research interests: renovation of buildings. 